in the control group. The increase in haemoglobin in the higher ranges occurred mainly in the first six months of use. In the range below $13 \mathrm{~g} . / 100 \mathrm{ml}$. there were no differences from the control group. Some formulations, especially those containing norethisterone acetate as progestogen have greater effect than others in raising haemoglobin concentrations.

Diminished blood loss alone does not account for all the changes observed. Haemoconcentration may occur in some subjects; if this is so the resulting increased viscosity may have some bearing on thrombotic phenomena. A further possible explanetion is corticosteroid stimulation of bone-marrow activity.

We wish to thank the Managing Committee of the Family Planning Association, Dr. Hilary Hill, and Dr. Mary Pollock for their helpful co-operation. The work was supported by grants from the Medical Research Council and the North-west Metropolitan Regional Hospital Board. Requests for reprints should be made to J. Fielding.

\section{REPERENCES}

Burton, J. L. (1967). Lancet, 1, 978.
Davidson, L. S. P., Donaldson, G. M. M., Lindsay, S. T., and McSorley, J. G. (1943). Brit. med. 3., 2, 95. de Leeuw, Nannie K M.. Lowenstein, L., and Yang-shu Hsieh (1966). Medicine (Baltimore), 45, 291.

Fielding, J., O'Shaughnessy, M. C., and Brunström, Gillian M. (1965). Lancet, 2, 9.

Kilpatrick, G. S., and Hardisty, R. M. (1961). Brit. med. 3., 1, 778.

Verwilghen. R.. Louwagie, A., Waes, J., and Vandenbroucke, J. (1966). Brit. F. Haemat., 12, 712 .

\title{
Psychiatric Study of a Consecutive Series of 19 Patients with Regional Ileitis*
}

\author{
FRED FELDMAN, M.D.; DAVID CANTOR, M.D.; SIDNEY SOLL, M.D.; WILLIAM BACHRACH, M.D.
}

Bris. med. .9., 1967, 4, 711-714

This paper reports a study of psychiatric factors in regional ileitis. The study parallels a similar survey (Feldman et al., 1967) in which we reported a series of 34 unselected cases of ulcerative colitis. In the latter inquiry a disease regarded by many psychiatrists as an unimpeachably psychosomatic illness was found to have probably no essential emotional causation.

Regional ileitis, a disease of obscure origin, has not attained the same almost classical reputation of ulcerative colitis as a psychosomatic illness. Nevertheless, since 1935 a number of authors have expressed the opinion that regional ileitis is a psychosomatic disease. A leading American textbook (Beeson and McDermott, 1967) stated: "It is thought that the repeated impact of emotional stress may give rise to dysfunction of the small intestine, with subsequent structural changes. This is supported by the clinical observation that recurrent symptoms are, at times, chronologically related to disturbing psychologic events."

\section{Relation between Regional Ileitis and Ulcerative Colitis}

The question is still open whether regional ileitis is actually a separate pathological entity from ulcerative colitis. Many physicians-for example, Eisenstadt (1965a), Ross (1965), and Crohn (1965)-say they are but different manifestations of the same disease. If this is true, then why has there been such prominence given to the notion of ulcerative colitis as a psychosomatic disease compared with the lesser emphasis on regional ileitis ? The question is still very controversial. However, evidence for suspecting that there is a strong relation between the two diseases is found in: (1) their beyond-chance genetic coincidence (Crohn and Yarnis, 1958 ; Sherlock et al., 1963 ; Edwards and Truelove, 1964 ; McConnell, 1965); (2) the association of both diseases with ankylosing spondylitis (McBride et al., 1963 ; McConnell, 1965 ; Acheson, 1965) ; (3) immunological studies (Phear, 1958; Taylor, 1965; Acheson, 1965); (4) the higher risk in Jews, of approximately the same order of magnitude for both diseases (Acheson, 1960 ; Acheson and Nefzger, 1963); (5) a number of cases where the condition of the colon suggested

- From the Department of Psychiatry and Department of Medicine, Cedars-Sinai Medical Centes, Mount Sinai Division, Los Angeles, California. that both diseases were present (Lumb, 1951 ; Porritt and Hunt, 1960) ; (6) the occurrence of the same complications, including erythema nodosum, pyoderma gangrenosum, arthritis, uveitis, and conjunctivitis ; and (7) the many overlapping clinical features of the diseases, so that one is sometimes misdiagnosed for the other (Cooke and Brooke, 1955 ; Yarnis, 1955 ; Hendrix, 1964).

In our small series of 19 cases a number of the foregoing features were present. (1) Genetic coincidence: a 47-year-old man with onset of regional ileitis at 19 had a brother who had ulcerative colitis at 16 and a sister who had ulcerative colitis at 40. (2) Ankylosing spondylitis: one of our patients had ankylosing spondylitis preceding the onset of regional ileitis. (3) Higher risk in Jews : 10 of the 19 patients were Jews, a higher proportion than would have been expected from the wide referral area. (4) Complications: a 19-year-old girl had erythema nodosum. (5) Overlapping clinical features: three cases were first diagnosed as ulcerative colitis, and several months of careful study were required to confirm the correct diagnosis of regional ileitis.

\section{Validation of Psychosomatic Disease}

The term "psychosomatic disease" has gone somewhat out of vogue during the past few years. It is now more fashionable to speak of "multifactorially-caused diseases" in referring to illness of undetermined origin. Nevertheless, if one of the components of an illness is psychosomatic, then an emotional cause of some type must be presumed to exist, or the disease cannot occur. In our study of ulcerative colitis we set up a catalogue of criteria for validating whether one essential component of a disease's cause was psychogenic. The same criteria have been examined for evidence of a psychogenic factor in regional ileitis. The seven criteria are: (1) a characteristic personality disorder or other serious psychiatric illness ; (2) a clear emotional precipitating factor chronologically related to the illness ; (3) general, conscious stress ; (4) basic emotional problems of long duration (unconscious stress); (5) alternation of symptoms, or syndrome shift ; (6) characteristic patterns of illness in the life history ; and (7) efficacy of psychotherapy. 


\section{Material and Method}

Nineteen patients with regional ileitis were studied, constituting every known patient with regional ileitis admitted to the Mount Sinai Hospital between August 1964 and June 1967. Tables I and II list age, sex, severity of disease, length of illness, area of involvement, patients requiring surgery, and complications. Two types of control groups were used. The first was a control group only in the loosest sense, since it consisted of the general population, divided into normal and abnormal according to arbitrary criteria. The second control group comprised the first 74 consecutive patients admitted to the gastroenterology service while the study on regional ileitis was in process. No patients with disease of the large intestine were included.

Table I.-Age Groups and Sex Distribution of 19 Regional Ileitis Patients

\begin{tabular}{c|c|c|c}
\hline $\begin{array}{c}\text { Age Group } \\
\text { (At Time of Onset) }\end{array}$ & Males & Females & Total \\
\hline $10-20$ & 8 & 2 & 10 \\
$21-30$ & 1 & 3 & 4 \\
$31-40$ & 1 & 1 & 2 \\
$41-50$ & - & 1 & 1 \\
$51-60$ & - & 1 & 1 \\
$61-70$ & & 1 & 1 \\
\hline
\end{tabular}

\section{TABLE II.-Other Clinical Data on 19 Regional Ileitis Patients}

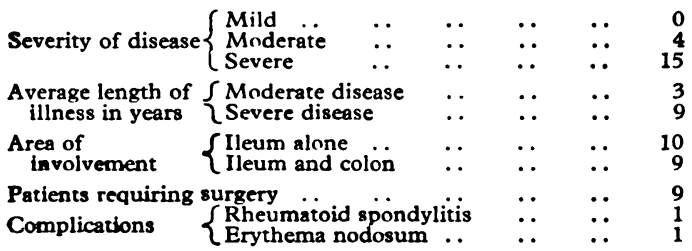

The team members were essentially those who conducted the concurrent study on ulcerative colitis, and consisted of a psychiatrist, physician, and two gastroenterologists. Each patient had two standard psychiatric interviews by the team, of the free-association type, but eventually including a discussion of sufficient current and past material to yield data for scoring 65 variables regarded as salient for personality evaluation (Table III). Subsequently the team saw the patient as often as possible during his hospital stay. Each patient was designated as "normal" or "abnormal" in each of the 65 categories of the protocol. Normal was scored as 3,4 , or 5 ; abnormal as 1 or 2. A normal distribution curve was used (Fig. 1). The curve

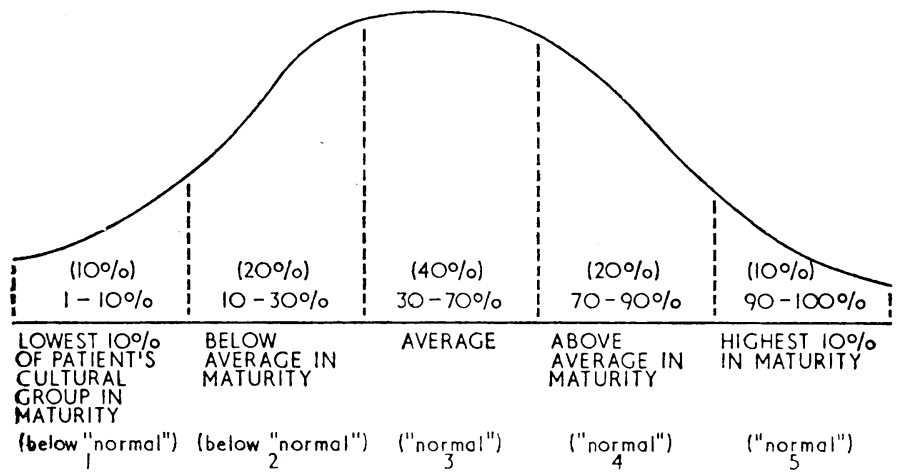

FIG. 1.-Normal distribution curve.

refers to the general population-that is, an arbitrary assumption was made that approximately $70 \%$ of the general population was "normal" and 30\% definitely "abnormal." It may be noted that four recent large epidemiological studies of psychiatric illness in general populations have confirmed the approximate correctness of this original guess at the distribution of " normality" (Essen-Möller, 1956; Srole et al., 1962; Leighton et al., 1963 ; Bahn et al., 1967).

\section{Results}

Personality Types and Psychiatric Illness.-Seventeen of the 19 patients were regarded as essentially "normal" within the limits we have described, and two were "abnormal." The two abnormal patients were a compulsive and somewhat impulsive man of 30 and an impulsive, somewhat eccentric, adventurous woman of 32. Both, however, had many ego strengths. Neither was psychotic. The other 17 patients were eight diagnosed as normal passive personality types and nine as normal aggressive types. There were no other significant psychiatric diagnoses, except in the 68 -year-old woman who had had moderate phobias 10 years before the onset of the regional ileitis.

Precipitating Factors and Chronological Relations.-There were no cases where a significant precipitating factor was

TABLE III.-List of Varables for Personality Evaluation

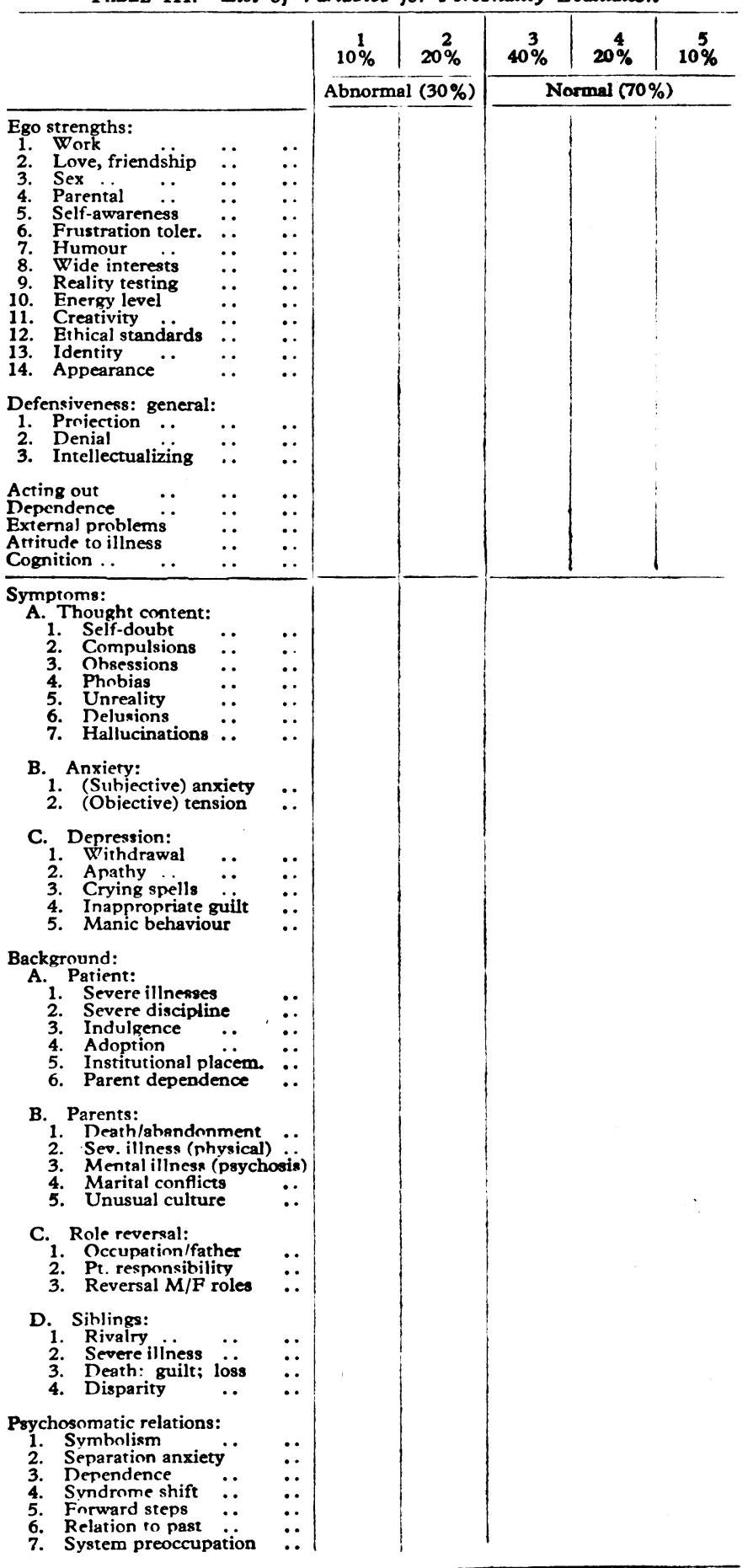


thought to have occurred close in time to the onset of regional ileitis. In two instances there appeared to be significant stress at the time of relapses. However, the total number of " attacks," "relapses," or "exacerbations" was quite high (prubably numbering 40 or more for the 19 patients), and the figure of two, associated with stress, would therefore appear small. There were no instances of extreme sepurution anxiety at the time of either onset or relapse, and no instances where a fear of taking forward steps in career, education, or marriage seemed crucial.

General Conscious Stress, Perhaps Cumulative.-In one case there was the possibility of long stress, associated with work, before relapses. Onset of the illness, however, had occurred 10 years previously, when the patient was in college. Moreover, be enjoyed his work, and ranked very high in professional capacity and conscientiousness. There were four other cases in which moderate stress was present before a relapse.

Basic or Nuclear Emotional Problems, with Significant Background Features, Symbolicully Related to the Illness (Unconscious Stress). - There were six cases in which the total background or dynamic factors were of some significance, but none was extreme. It was felt that none of the patients had had nuclear conflicts in his earlier years that were definitely expressing themselves symbolically in the form of the somatic illness.

Alternation of Symptoms, or Syndrome Shift.-No true alternation of either psychiatric or physical symptoms with the regional ileitis was encountered in the history or hospital course of the patients. There was one instance of rheumatoid spondylitis, which had begun before the ileitis but did not alternate with it. Moderate depression was present in four cases but was linked to the severity of the illness.

Characteristic Patterns of Illness in the Life History.-There was no significant hypochondriasis, even in the two "abnormal" patients. There was no history of preoccupation with bowel habits.

Efficacy of Psychotherapy.-Five patients had had psychotherapy ranging from one month to one and one half years. It had effected no improvement in the regional ileitis itself in any case.

\section{Results in Control Group}

The results in the 74 control patients are not described in detail here, but are compared with the regional patients in Fig. 2. In general, the control patients showed as much psychopathology as, or more than, the regional ileitis cases.

\section{Discussion}

Regional ileitis has been arraigned as a psychosomatic disease by a number of psychiatric investigators and denied as one by

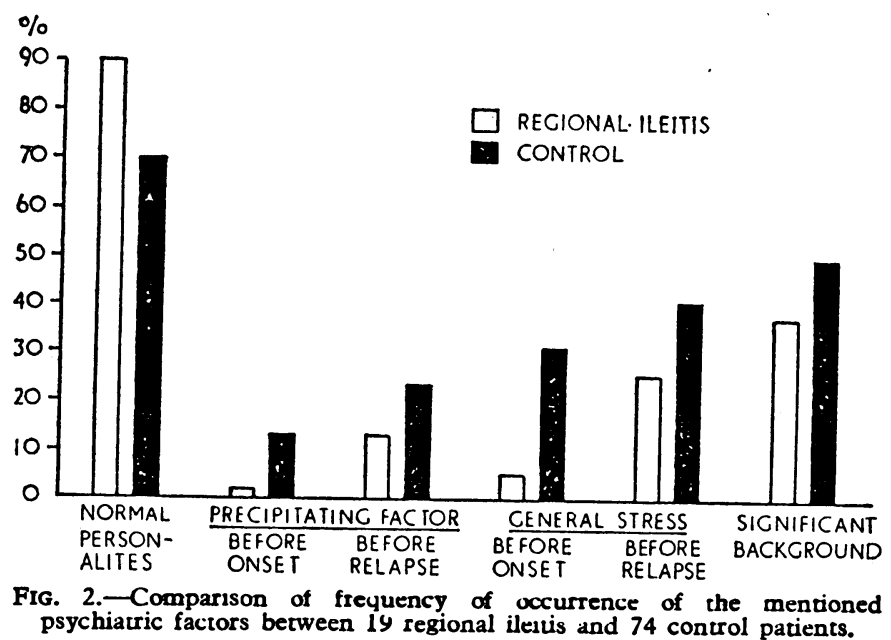

a few. Gastoenterologists generally have avoided a definite statement about the role of emotions. Some, including Crohn himself (Crohn and Yarnis, 1958), have stated that there is no support for the psychosomatic concept. No studies and no statements have been sufficiently definitive to give physicians a firm foundation for their thinking. We found that many of our patients had been told by one or more physicians that emotional tension might be the cause of their illness. One of the patients, a busy surgeon, had been advised by several physicians to change his specialty to some field of medicine where there would be "Yittle tension."

The psychiatric literature is remarkably scanty-approximately 13 studies in 30 years. So limited and contradictory a literature, to make even the impact it has on medical education, must have derived from other sources. The unavoidable association with ulcerative colitis has prevailed to some extent, and the unconscious need to divine magical answers for diseases of unknown cause has played a part. Arieti (1959) states that " regional ileitis and ulcerative colitis are conditions involving tissue breakdown that are, at least in part, determined by emotional problems." Kaelbling and Patterson (1966) assert that "importance is attached to the significance of emotional factors in regional ileitis."

The studies by psychiatrists are subject to the following criticisms: (1) they sometimes dealt with very few patients, studied at great length ; $(2)$ there were no unselected consecutive series ; (3) some were retrospective studies; (4) patients were often only those selected by other physicians for referral to psychiatrists because of concurrent but not necessarily associated emotional problems; and $(S)$ the criteria for emotional evaluation were usually not given in detail.

The studies by psychiatrists who favoured the psychosomatic explanation included series of seven patients (Stewart, 1949), 11 patients (Paulley, 1948), four patients (Grace, 1953), one patient (Sperling, 1960), and two patients (Mersereau, 1963). Two psychiatric studies objecting to the psychosomatic hypothesis were those involving eight patients (Kraft and Ardali, 1964) and 16 patients (Crocket, 1952). The latter was the only series approaching ours in size, and was carefully done, but the material was not consecutive or unselected.

The reports by gastroenterologists referring to psychiatric causation were impressionistic, and no rigorous psychiatric evaluations were carried out. Reports favouring the psychosomatic hypothesis somewhat vaguely were those of 40 cases (Dashiell et al., 1951), 20 cases (Richman, 1955), 34 cases (Armitage and Wilson, 1950), 33 cases (Hunt, 1965), and no definite number of cases (Schepers, 1945; Eisenstadt, 1965b).

In contrast to the papers noted above there are many hundreds by gastroenterologists, who reported much longer series of cases, including collections of 700 patients (Crohn and Yarnis, 1958), 600 patients (Van Patter et al., 1954), 500 patients (Turner, 1953), and other large series (Strömbeck, 1937 ; Warren and Miller, 1942; Tallroth, 1943 ; Janowitz, 1955). In these studies, and in many others reviewed, either no reference was made to psychiatric factors or they were thought to be minimal or insignificant. The impression gained is that gastroenterologists regard their patients as no different from any other seriously ill patients.

\section{Summary and Conclusions}

Nineteen consecutive unselected cases of regional ileitis were studied psychiatrically. No evidence was found that an emotional factor was a significant aetiological component. Seventeen of the 19 patients were regarded as "normal." The results of a study such as this are qualified by questions concerning the concept of normality; our recognition that the assumption of $70 \%$ normality in the general population is open to criticism ; the reliability of diagnostic criteria in psychiatry; the difficulty of assessing deeper problems with brief interviews; 
and the central problem of whether primary psychosomatic disease exists. Nevertheless the significant emotional factors relating to psychosomatic illness noted in the literature were investigated and found not to apply to any important degree. We do, therefore, raise the question whether the disease should be regarded as psychosomatic in any way.

\section{BIBLIOGRAPHY}

Acheson, E. D. (1960). Gut, 1, 291.

(1965). Chapter 11 in Badenoch and Brooke (1965)

1965). Gastroenterology, 44,

Arieti, S (1959). American Hanubook of Psychialry. New York.

Armitage, G., and Wilson, M. (1950) Brit. F. Surg., 38, 182.

Atwell, J. D., Duthie, H. L., and Goligher, J. C. (1965). Ibid., 52, 966

Arlett S O. (1966). Brit med Goligher,

Badenoch. J., and Brooke, B. N."(1965). Recent Advances in Gastroenterology. Boston.

Bahn, A. K., Gardner. E. A., Alltop, L., Knatterud, G. L., and Solomon, M. (1967). Amer. f. publ. Hlth, 56, 2033.

Bargen, J A. (1955). Wis. med. f., 54, 367

(1966). Dis. Colon Rect., 9. 13.

Beeson, P. B., and McDermott, W. (editors) (1967). Cecil-Loeb Textbook of Medicine, 12th ed. 1967.

Blackburn. G., Hadfield, G., and Hunt, A. H. (1939). St. Bart. Hosp. Rep., 72, 181.

Bockus, H. L. (1945). I Amer. med. Ass., 127, 449.

(1965). Gastroenterology, 2nd ed., vol. 3. Philadelphia.

Cave, H.W. (1945). F. Amer. med Ass., 127, 208.

Colcock, B. P., and Vansant, J. H. (1960). Lahey Clin. Bull., 12, 53

Cooke, W. T., and Brooke, B. N. (1955). Quart. F. Med., 24, i.

Crocket, R. W. (1952). Lancet, 1, 946.

Crohn, B. B. (1965). Dis. Colon Rect., 8, 3.

and Yarnis, H. (1958). Regional lleitis, 2nd ed. New York

Dashiell, G G., Kirsner, J. B., Klotz, A. B., and Palmer, W. L. (1951) Med. Clin. N. Amer., 35, 227.

Dennis, C., and Eddy, F. D. (1947). Proc. Soc. exp. Biol. (N.Y.), 65, 306

Dragstedt, L. R., and Owens, F. M., jun. (1943). Ibid., 53, 152.

Edwards, F. C., and Truelove, S. C. (1964). Gut, 5, 1.'

Eisenstadt, H. B. (1965a). Amer. F. Gastroent., 43, 560.

- (1965b). Amer f. Prociol., 16, 370.

Essen-Möler, E. (1956). Acta psychiat. scand., Suppl. No. 100

Feldman, F., Cantor, D., Sull, S., and Bachrach, W. (1967). Brit. med. $7 ., 3,14$

Flanagan, J. C. (1964). Sth. med. f. (Bgham, Ala.), 57, 801.

Grace. W. J. (1953). Gastroenterology, 23, 542.

Hendrix, T. (1964). Chapter 4 in Mellinkoff (1964).
Hunt, T. (1965). Trans. med. Soc. Lond., 81, 87.

Janowitz, H. D. (19,5). F. Mi Sinai Hosp., 22, 223

Kaelbling, R., and Patterson, R. M. (1966). 'Eclectic Psychiatry. Springfield, III.

Kiefer, E. D. (1953). Lahey Clin. Bull., 8, 149.

Kraft, I. A., and Ardali, C. (1964). Sth. med. F. (Bgham, Ala.), 57, 799.

Leighton, D. C., Harding, J. S., Macklin, D. B., Macmillan, A. M., and Leighton, A. H. (1963). The Character of Danger. New York.

Lumb, G. (1951;. Brit. 7. Surg., 39, 233.

McBride, J. A., King, M. J., Baikie, A. G., Crean, G. P., and Sircus, W. (1963). Brit. med. F., 2, 483.

McConnell, R. B. (1965). Chaprer 1 in Badenoch and Brooke (1965).

Machella, T. E. (1966). In Principles of Internal Medicine, edited by T. R. Harrison. R. D Adams, I. L. Bennett, W. H. Resnik, G. W. Thorn, and M. M. Wintrobe. New York.

Maddison, T. G., and Hyde, I. (1935). Arch. Dis. Childh., 30, 469.

Marshall, S. F., and Mathieson, W. L. (1955). Lahey Clin. Bull., 9, 66.

Mellinkoff, S. M. (editor) (1964). Differential Diagnosis of Diarrhea. New York.

Mersereau, B. S. (1963). Amer. ₹. Psychiat., 119, 1099.

Moseley, J. F., Marshak, R. H., and Wolf, B. S. (1960). Amer. Y. Roentgenol., 84, 532

Paulley, J. W. (1948). Lancet, 1, 923.

Paulley, (1949). Proc. roy. Soc. Med., 42, 241 (1959). Proc. roy. Soc. Med., 42, (1956). Lancet, 2, 215

Phear, D. (1958). Ibid., 2, 1250

Porritt, A., and Hunt, T C. (1960). Proc. roy. Soc. Med., 53, 373.

Pumphrey, R. E. (1938). Proc. Mayo Clin., 13, 539.

Richman, A. (1955). 7. Mt Sinai Hosp., 22, 175.

Ross, S. T. (1965). Surgery, 58, 357.

Schepers, G. W. H. (1945). Amer. $\dot{f}$. dig. Dis., 12, 97.

Schepers, G. W. Hn. Paediat. (Basel), 165, 281.

Sherlock, P., Bell, B. M., Steinberg, H., and Almy, T. P. (1963). Gastroenterology, 45, 413 .

Sperling, M. (1960). Int. F. Psycho-Anal., 41, 612.

Srole, L., Langner, T. S., Michael, S. T., Opler, M. K., and Rennle, T. A. C. (1962). Mental Health in the Metropolis. New York.

Stewart, W. A. (1949). N.Y. St. F. Med., 49, 2820

Storrs, R. C., and Hoekelman, R. A. (1953). New Engl. F. Med., 248, 320

Strömbeck, J. P. (1937). Acta chir. scand., 80, Suppl. No. 50, 1.

Tallroth, A. (1943). Ibid., 88, 407.

Taylor, K. (1965). Chapter 2 in Badenoch and Brooke (1965).

Turner, D A. (1953). Univ. W. Ont. med. ₹., 23, 160.

Turner, D A. (1953). Univ. W. Ont. med. f., 23, 160 . an Patter, W. N., Bargen. J. A., Dockerty, M. B., Feldman, W. H.,
Mayo, C. W., and Waugh, J. M. (1954). Gastroenterology, 26, 347. Walter, L. E., and Chaffin, L. (1957). West. F. Surg., 65, 354

Warren, R., and Miller, R. H. (1942). New Engl. J. Med., 226, 589.

Winkelman, E. I. (1967). Pediat. Clin. N. Amer., 14, 141.

Yarnis, H. (1955). 7 Mt Sinai Hosp., 22, 159.

Zetzel, L. (1967) In Cecil-Loeb Textbook of Medicine, edited by P. B. Beeson and W. McDermot.

\title{
Evaluation of a Screening Survey for Anaemia in Adult Non-pregnant Women
}

\author{
P. C. ELWOOD,* M.D., D.P.H., D.C.H. ; W. E. WATERS,* M.B., B.S., D.I.H. ; W. J. GREENE,* M.B., CH.B. \\ M. M. WOOD, $\dagger$ B.SC.
}

WITh THE Assistance of E. H. EVANS, $\ddagger$ M.D., M.R.C.P., J. DE SWIET, $\ddagger$ M.D., M.R.C.P., AND J. V. WILLIAMS, $\ddagger$ M.B., M.R.c.P.

Brit. med.F., 1967, 4, 714-717

Considerable interest has been shown recently in community health screening (Backett, 1960 ; Wilson, 1963 ; Acheson, 1963 ; Horne, Clark, and Patterson, 1967). The value of any healthscreening procedure depends both on the proportion of persons detected with the disease (or diseases) being sought, or with treatable associated conditions, and on the importance to life or health of these conditions. The number of affected persons detected is dependent both on the prevalence of the disease, or the conditions associated with it, in the community to which screening is offered, and on the nature and extent of selection, if any, of those members of that community who co-operate. In fact very little is known about the selection of persons who readily co-operate in health-screening procedures except in a very few situations, such as mass miniature radiography (Brad-

- From the Epidemiological Research Unit of the Medical Research Council, Cardiff.

† External Staff, Medical Researcn Council, Llandough Hospital, Penarth. $\ddagger$ Physicians, Liwynypia Hospital, Rhondda. bury, 1948) and cervical cytology (Wakefield and Barić, 1965), in both of which it seems that affected individuals are, on average, less likely to co-operate than those who are unaffected, though in coal-workers' pneumoconiosis (Cochrane, 1951) and possibly in other compensatable industrial diseases the reverse is probably true. Other than in a few such cases very little is known about how persons who spontaneously attend community screening clinics differ from other members of the community.

Assessment of the importance of the conditions detected during a screening survey necessitates value judgements which are not easily made and which ideally should be based on data relating to changes in the subsequent mortality or morbidity in the community screened. In the haematological community study described here the initial survey was evaluated as an ad hoc health-screening procedure. This evaluation was based on the following: (1) the proportion of subjects seen who were thought to be "anaemic," (2) the symptomatic benefit which resulted from iron therapy in these subjects, and (3) the pre- 